\title{
IR Spectroscopic Study of Silicon Nitride Films Grown at a Low Substrate Temperature Using Very High Frequency Plasma-Enhanced Chemical Vapor Deposition
}

\author{
Shin-ichi Kobayashi \\ Department of Electronics and Mechatronics, Tokyo Polytechnic University, Atsugi, Japan \\ Email: koba@em.t-kougei.ac.jp
}

How to cite this paper: Kobayashi, S. (2016) IR Spectroscopic Study of Silicon Nitride Films Grown at a Low Substrate Temperature Using Very High Frequency PlasmaEnhanced Chemical Vapor Deposition. World Journal of Condensed Matter Physics, 6, 287-293.

http://dx.doi.org/10.4236/wjcmp.2016.64027

Received: September 23, 2016

Accepted: October 30, 2016

Published: November 2, 2016

Copyright $\odot 2016$ by author and Scientific Research Publishing Inc. This work is licensed under the Creative

Commons Attribution International

License (CC BY 4.0).

http://creativecommons.org/licenses/by/4.0/

\begin{abstract}
Hydrogenated amorphous silicon nitride $\left(\mathrm{a}-\mathrm{SiN}_{\mathrm{x}}: \mathrm{H}\right)$ films have been grown from a $\mathrm{SiH}_{4}-\mathrm{N}_{2}$ gas mixture through very high frequency (VHF) plasma-enhanced chemical vapor deposition (PECVD) at $50^{\circ} \mathrm{C}$. The films are dense and transparent in the visible region. The peak frequency of the $\mathrm{Si}-\mathrm{N}$ stretching mode in the IR absorption spectrum increases with increasing $\mathrm{N}-\mathrm{H}$ bond density, which is similar to the behavior of a-SiN ${ }_{\mathrm{x}}: \mathrm{H}$ films grown from $\mathrm{SiH}_{4}-\mathrm{NH}_{3}$ gas. During storage in a dry air atmosphere, the $\mathrm{Si}-\mathrm{O}$ absorption increases. A large shift in the peak frequency of the $\mathrm{Si}-\mathrm{N}$ stretching mode in the initial stage of oxidation, which is higher than the shift expected from the increase in the $\mathrm{N}-\mathrm{H}$ bond density, is mainly caused by the change in the sum of electronegativity of nearest neighbors around the $\mathrm{Si}-\mathrm{N}$ bond due to the increase in the $\mathrm{Si}-\mathrm{O}$ bond density.
\end{abstract}

\section{Keywords}

Silicon Nitride, PECVD, VHF, FTIR

\section{Introduction}

Hydrogenated amorphous silicon nitride $\left(\mathrm{a}-\mathrm{SiN}_{\mathrm{x}}: \mathrm{H}\right)$ films are useful as barrier layers to prevent the diffusion of oxygen and water into optical devices. To protect optical devices against thermal damage during the deposition of an a- $\mathrm{SiN}_{\mathrm{x}}: \mathrm{H}$ film, a plasmaenhanced chemical vapor deposition (PECVD) system is used at a low substrate temperature. However, these a-SiN $: \mathrm{H}$ films generally have high densities of $\mathrm{N}-\mathrm{H}$ bonds and $\mathrm{Si}-\mathrm{H}$ bonds; consequently, the aerial oxidation of $\mathrm{H}$-terminated or dangling bonds 
can easily occur. Therefore, it is important to clarify the mechanism of the initial oxidation process during air exposure to protect optical devices, such as organic photovoltaic devices, which require high performance barrier films.

A-SiN $\mathrm{N}_{x}: \mathrm{H}$ films are usually grown from a $\mathrm{SiH}_{4}-\mathrm{NH}_{3}$ gas mixture. However, in order to obtain low-hydrogen-content a-SiN $\mathrm{x}: \mathrm{H}$ films, it is preferable to use $\mathrm{N}_{2}$ instead of $\mathrm{NH}_{3}$ as the nitrogen source because $\mathrm{N}_{2}$ does not contain $\mathrm{N}-\mathrm{H}$ bonds. Usually, a-SiN $\mathrm{x}: \mathrm{H}$ films are deposited using a PECVD system at a $13.56 \mathrm{MHz}$ excitation frequency. Shifting the discharge frequency into the very high frequency (VHF) region results in a higher deposition rate for PECVD in a conventional diode-type reactor for a-Si:H [1], $\mu \mathrm{c}-\mathrm{Si}$ [2], and a-SiN $\mathrm{x}: \mathrm{H}$ films deposited from a $\mathrm{SiH}_{4}-\mathrm{NH}_{3}-\mathrm{N}_{2}$ gas mixture [3]. Thus far, a-SiN $\mathrm{x}: \mathrm{H}$ films have not been produced through VHF-PECVD from a $\mathrm{SiH}_{4}-\mathrm{N}_{2}$ gas mixture without $\mathrm{NH}_{3}$ gas, except for one example of atmospheric-pressure (AP) PECVD at 150 $\mathrm{MHz}$ [4]. Thus, in a previous study, the VHF excitation of plasma was attempted to decompose the $\mathrm{N}_{2}$ gas diluted $\mathrm{SiH}_{4}$ gas in a conventional PECVD reactor under reduced pressure at $350^{\circ} \mathrm{C}$ and we revealed that VHF plasma can create a transparent film with lower excitation power compared to that resulting from conventional RF plasma [5].

In this paper, the deposition of $\mathrm{a}_{-} \mathrm{SiN}_{\mathrm{x}}: \mathrm{H}$ films at $50^{\circ} \mathrm{C}$ is presented. The effects of power density on the deposition rate, optical bandgap $\left(E_{\mathrm{opt}}\right)$, and $\mathrm{Si}-\mathrm{H}$ and $\mathrm{N}-\mathrm{H}$ bond densities $\left(N_{\mathrm{Si}-\mathrm{H}}\right.$ and $\left.N_{\mathrm{N}-\mathrm{H}}\right)$ in the resulting a-SiN $\mathrm{N}_{\mathrm{x}}: \mathrm{H}$ films are investigated. The changes in the local structure of the films that occurred during storage in dry air, as detected using Fourier transform infrared spectroscopy (FTIR), were also studied to understand the stability mechanism in the film properties.

\section{Experimental}

The a-SiN $\mathrm{x}_{\mathrm{x}}: \mathrm{H}$ films were grown through the VHF-PECVD of a $\mathrm{SiH}_{4}-\mathrm{N}_{2}$ gas mixture in a diode-type reactor, in which each electrode had a diameter of $60 \mathrm{~mm}$ and the electrode separation was $10 \mathrm{~mm}$. The ultimate vacuum pressure of the reactor was $\sim 10^{-6} \mathrm{~Pa}$ and the total pressure of $2 \% \mathrm{SiH}_{4}$ diluted with $\mathrm{N}_{2}$ gas was $200 \mathrm{~Pa}$ with a flow rate of 30 sccm. Fused silica and $\mathrm{Si}(100)$ wafers were used as the substrates and the substrate temperature was maintained at $50^{\circ} \mathrm{C}$ during the deposition. The VHF frequency was $150 \mathrm{MHz}$ and the VHF power density was varied from 70 to $385 \mathrm{~mW} / \mathrm{cm}^{2}$. The typical film thickness was $300 \mathrm{~nm}$. The Tauc optical bandgap $E_{\text {opt }}$ was obtained from the optical transmittance spectrum. The Si-H bond density $N_{\mathrm{Si}-\mathrm{H}}$ and $\mathrm{N}-\mathrm{H}$ bond density $N_{\mathrm{N}-\mathrm{H}}$ were calculated from the FTIR absorption spectrum in transmission mode through the expression:

$$
N_{X-H}=A_{X-H} \times \int(\alpha(v) / v) \mathrm{d} v
$$

where $\mathrm{X}=\mathrm{Si}$ or $\mathrm{N}, \alpha(v)$ is the absorption coefficient and $v$ is the wavenumber [6]. The calibration factor $A_{X-H}$ values of the Si-H $\left(\sim 2100 \mathrm{~cm}^{-1}\right)$ and N-H $\left(\sim 3300 \mathrm{~cm}^{-1}\right)$ stretching modes are $1.7 \times 10^{20}$ and $2.8 \times 10^{20}$, respectively [7].

In order to investigate the local structural changes that occurred in a-SiN $\mathrm{x}: \mathrm{H}$ films during storage, the samples were stored in an FTIR system containing dry air for 100 
days with the temperature kept at $25^{\circ} \mathrm{C}$ and the relative humidity (RH) maintained below $0.5 \%$.

\section{Results and Discussion}

Figure 1 shows the VHF power density dependence of $E_{\mathrm{opt}}$ of the a-SiN $: \mathrm{H}$ films. $E_{\mathrm{opt}}$ has a lower value of $3.7 \mathrm{eV}$ at a VHF power density of $70 \mathrm{~mW} / \mathrm{cm}^{2}$; it is suggested that the electron-impact dissociation of $\mathrm{N}_{2}$ is insufficient to obtain a transparent film at a low VHF power density. $E_{\text {opt }}$ becomes $\sim 5 \mathrm{eV}$ when the VHF power density is greater than $140 \mathrm{~mW} / \mathrm{cm}^{2}$. At these values, $\mathrm{a}-\mathrm{SiN}_{\mathrm{x}}: \mathrm{H}$ films are transparent in the visible region and the deposition rate is $\sim 1 \mathrm{~nm} / \mathrm{s}$. The surface morphology and structure of the films were studied using a scanning electron microscope (SEM) and a transmission electron microscope (TEM). The films appear to be homogeneous and there is no evidence of a micro columnar structure which observed in [8]. A typical FTIR absorption spectrum of an a-SiN $\mathrm{x}_{\mathrm{x}} \mathrm{H}$ film is shown in Figure 2. The bands assigned to the Si-N stretching vibration centered at $\sim 850 \mathrm{~cm}^{-1}$, N-H bending mode at $1170 \mathrm{~cm}^{-1}$, Si-H stretching mode at $2100 \mathrm{~cm}^{-1}, \mathrm{~N}-\mathrm{H}$ stretching mode at $3340 \mathrm{~cm}^{-1}$, and Si-N breathing mode at $470 \mathrm{~cm}^{-1}$ can be clearly identified.

Figure 3 shows the VHF power density dependence of $N_{\mathrm{Si}-\mathrm{H}}$ and $N_{\mathrm{N}-\mathrm{H}}$ in the a-SiN $\mathrm{x}: \mathrm{H}$ films. At a VHF power density of $70 \mathrm{~mW} / \mathrm{cm}^{2}$, at which $E_{\text {opt }}$ is $3.7 \mathrm{eV}$, indicating a Si-rich a-SiN $\mathrm{N}_{\mathrm{x}} \mathrm{H}$ film, $N_{\mathrm{Si}-\mathrm{H}}$ is higher than $N_{\mathrm{N}-\mathrm{H}}$. As the VHF power is increased, $N_{\mathrm{N}-\mathrm{H}}$ slightly increases and then saturates, while $N_{\mathrm{Si}-\mathrm{H}}$ exponentially decreases, because an increase in the VHF power enhances the decomposition of $\mathrm{SiH}_{4}$ and $\mathrm{N}_{2}$ gases. Although $\mathrm{N}_{2}$ does not contain $\mathrm{N}-\mathrm{H}$ bonds itself, the $N_{\mathrm{N}-\mathrm{H}}$ value of the a-SiN $\mathrm{x}: \mathrm{H}$ films with an $E_{\text {opt }}$ of $\sim 5 \mathrm{eV}$ is of the order of $10^{22} \mathrm{~cm}^{-3}$. In Figure 4, it can be observed that the $\mathrm{Si}-\mathrm{N}$ stretching frequency increases with increasing $N_{\mathrm{N}-\mathrm{H}}$. This shift in the Si-N stretching frequency is induced by the back-bonding of the $\mathrm{H}$ atom, which is more electronegative than $\mathrm{Si}$, to the $\mathrm{N}$ atom of the $\mathrm{Si}-\mathrm{N}$ bonds. The peak frequencies of the $\mathrm{Si}-\mathrm{N}$

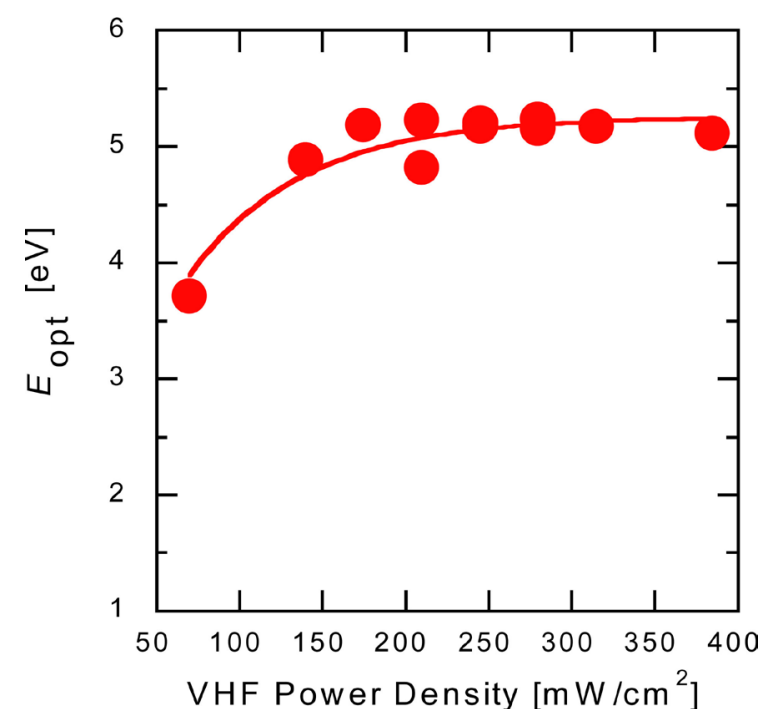

Figure 1. VHF power dependence of the optical bandgap of $\mathrm{a}-\mathrm{SiN}_{\mathrm{x}}: \mathrm{H}$ film. 


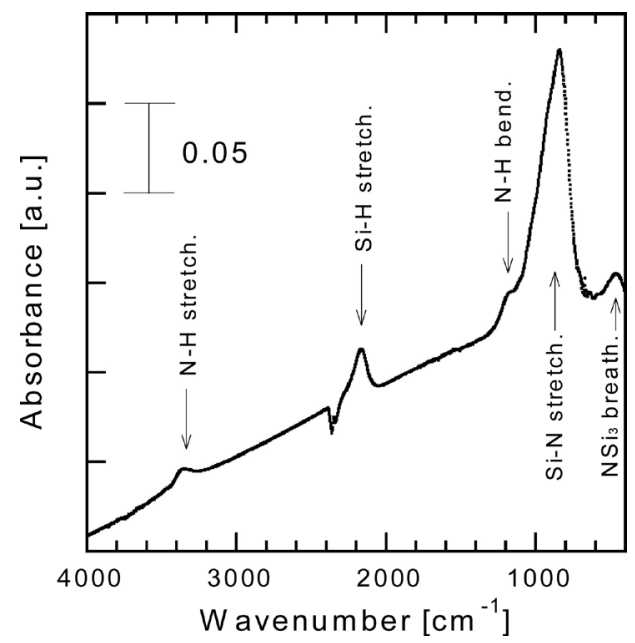

Figure 2. FTIR spectrum of an a-SiN ${ }_{x}: \mathrm{H}$ film deposited at $50^{\circ} \mathrm{C}$ with a VHF power density of $70 \mathrm{~mW} / \mathrm{cm}^{2}$.

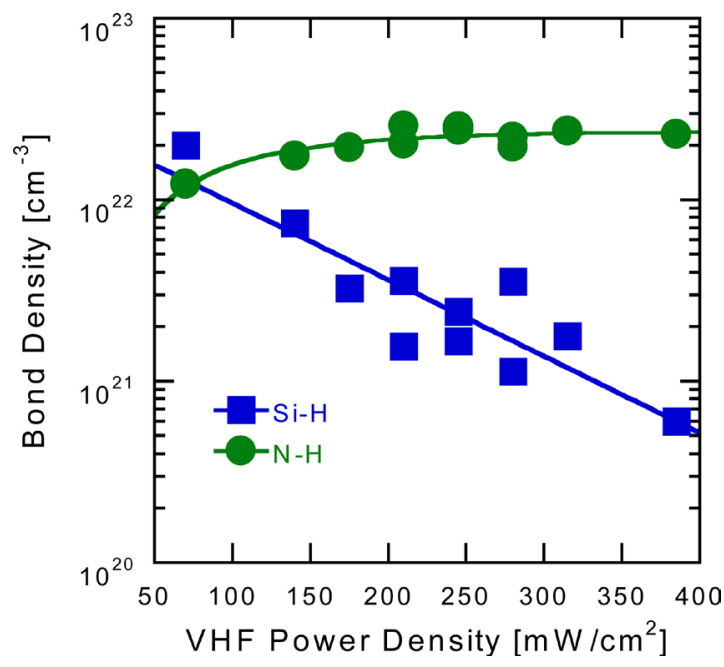

Figure 3. VHF power dependence of $\mathrm{Si}-\mathrm{H}\left(N_{\mathrm{Si}-\mathrm{H}}\right)$ and $\mathrm{N}-\mathrm{H}\left(N_{\mathrm{N}-\mathrm{H}}\right)$ bond densities.

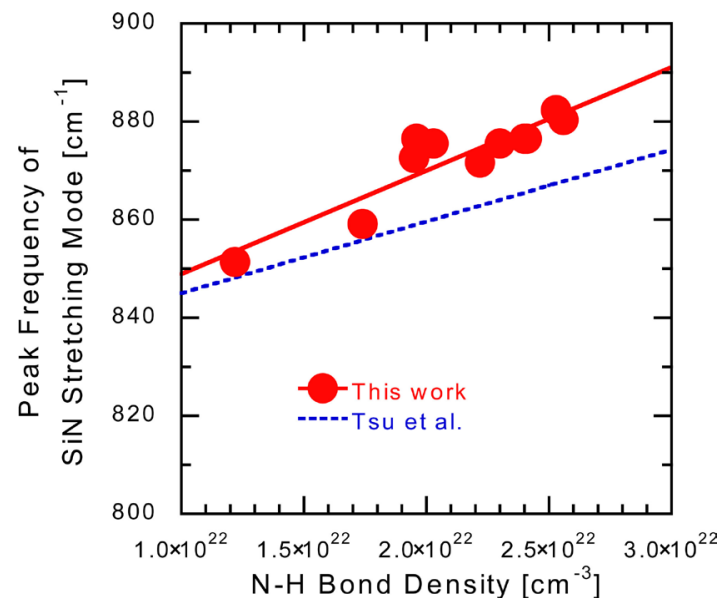

Figure 4. Peak frequency of the Si-N stretching mode as a function of the $\mathrm{N}-\mathrm{H}$ bond density $\left(N_{\mathrm{N}-\mathrm{H}}\right)$. 
stretching mode obtained in the present study are slightly higher than those obtained from films deposited from a $\mathrm{SiH}_{4}-\mathrm{NH}_{3}$ gas mixture reported by Tsu et al. [9].

Figures 5(a)-(c) show the FTIR spectra of the as-deposited and aged a-SiN $\mathrm{x}: \mathrm{H}$ films deposited at $210 \mathrm{~mW} / \mathrm{cm}^{2}$. The as-deposited a-SiN $\mathrm{x}_{\mathrm{x}}: \mathrm{H}$ film has an $E_{\mathrm{opt}}$ of $5.2 \mathrm{eV}, N_{\mathrm{N}-\mathrm{H}}$ of $2.6 \times 10^{22} \mathrm{~cm}^{-3}$, and $N_{\mathrm{Si}-\mathrm{H}}$ of $1.6 \times 10^{21} \mathrm{~cm}^{-3}$, respectively. The sample was fixed on the sample holder in the FTIR system containing dry air $\left(25^{\circ} \mathrm{C},<0.5 \% \mathrm{RH}\right)$ for 100 days, during which the peak frequency of the $\mathrm{Si}-\mathrm{N}$ stretching mode shifted from $880 \mathrm{~cm}^{-1}$ to $898 \mathrm{~cm}^{-1}$ (Figure 5(c)). Assuming that this shift was caused only by the change in the $N_{\mathrm{N}-\mathrm{H}}$ value in the same manner observed for the as-deposited film, as shown in Figure 4 , a large increase of $2.0 \times 10^{22} \mathrm{~cm}^{-3}$ in the $N_{\mathrm{N}-\mathrm{H}}$ value is required. To clarify the changes in the absorbance during storage, the difference between the as-deposited film and the same film aged for 100 days are depicted in Figures 5(d)-(f). The small increase of $1.0 \times 10^{21} \mathrm{~cm}^{-3}$ in the $N_{\mathrm{N}-\mathrm{H}}$ value during storage (Figure $5(\mathrm{~d})$ ) cannot explain the large shift of nearly $20 \mathrm{~cm}^{-1}$ in the peak frequency of the Si-N stretching mode during storage.

In Figure 5(f), the spectrum is clearly divided into six Gaussian peaks and valleys labeled as $v_{1}-v_{6}$. The absorbance at $1050 \mathrm{~cm}^{-1}\left(v_{5}\right)$ is assigned to $\mathrm{Si}-\mathrm{O}$ stretching mode and increases as the exposure time increases, implying that film oxidation occurred. The absorbance at $450 \mathrm{~cm}^{-1}\left(v_{1}\right)$, existing in the vicinity of the Si-N breathing mode $\left(470 \mathrm{~cm}^{-1}\right)$, is assigned to the $\mathrm{Si}-\mathrm{O}$ rocking mode. The increase of $13 \%$ in the integrated absorbance at $1170 \mathrm{~cm}^{-1}\left(v_{6}\right)$ is due to the $\mathrm{Si}-\mathrm{O}$ transverse mode [10] rather than the $\mathrm{N}-\mathrm{H}$ bending mode because the increase in the integrated absorbance at $1050 \mathrm{~cm}^{-1}\left(v_{5}\right)$ is $12 \%$ and the change in $N_{\mathrm{N}-\mathrm{H}}$ calculated from the $3340 \mathrm{~cm}^{-1}$ band during storage is small (4\%). Since the FWHM values of these peaks are at most $75-120 \mathrm{~cm}^{-1}$, increases in the spectrum derived from $\mathrm{Si}-\mathrm{O}$ bonds do not directly affect to the shift in the $\mathrm{Si}-\mathrm{N}$ stretching frequency.

For the Si-N stretching vibration at $750-1000 \mathrm{~cm}^{-1}$, while the intensities at $780 \mathrm{~cm}^{-1}$ $\left(v_{2}\right)$ and $835 \mathrm{~cm}^{-1}\left(v_{3}\right)$ obviously decrease, a peak simultaneously appears at $940 \mathrm{~cm}^{-1}$

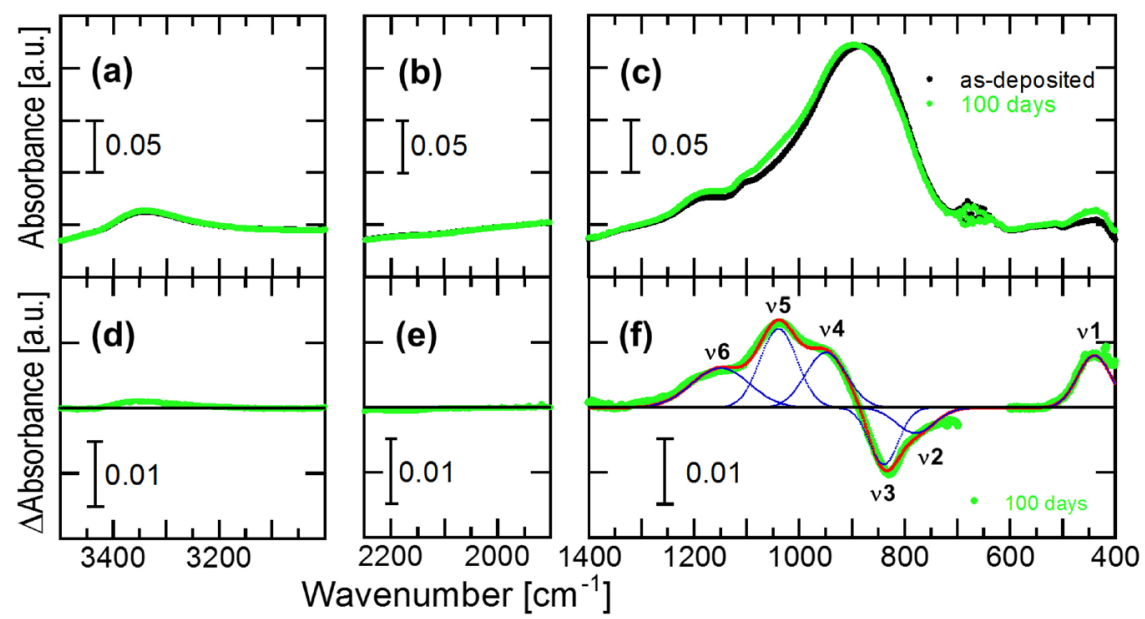

Figure 5. (a) - (c) FTIR spectra of the as-deposited and aged a-SiN ${ }_{\mathrm{x}}: \mathrm{H}$ films; (d) - (f) changes in FTIR spectra during storage. 
$\left(v_{4}\right)$. These peaks and valleys are the main causes for the peak shift of the Si-N stretching mode to a higher value at the initial stage of oxidation. As mentioned before, the increase in $N_{\mathrm{N}-\mathrm{H}}$ during storage is small. Therefore, the effect of increase in $N_{\mathrm{N}-\mathrm{H}}$ during storage on the shift in the peak frequency through changes in the sum of electronegativity of the nearest neighbors around the $\mathrm{Si}-\mathrm{N}$ bond, is small. On the other hand, oxidation of a-SiN $\mathrm{x}: \mathrm{H}$ films occurred during storage, thus, $\mathrm{Si}-\mathrm{O}$ bonds increased. This increase in the concentrations of the $\mathrm{O}$ atom, which is more electronegative than $\mathrm{N}$, backbonded to the $\mathrm{Si}$ atoms of the $\mathrm{Si}-\mathrm{N}$ bonds caused a new increase in absorption at the high-wavenumber side $\left(940 \mathrm{~cm}^{-1}, v_{4}\right)$. For the low-wavenumber side, there are some possible causes for the generation of valleys. When a peak appears in a spectrum due to changes in electronegativity of the nearest neighbors, a valley of almost identical area appears necessarily. The valley at the low-wavenumber side $\left(v_{3}\right)$ is considered to be caused by such a reduction with the generation of the new peak $\left(v_{4}\right)$. Meanwhile, Lucovsky and co-workers pointed out that the low-wavenumber side $\left(840 \mathrm{~cm}^{-1}\right)$ of the $\mathrm{Si}-\mathrm{N}$ stretching mode reflects the vibration of the $\mathrm{Si}-\mathrm{N}$ bonds, in which at least one $\mathrm{H}$ atom is back-bonded to the $\mathrm{Si}$ atom [11]; however, the change in the $N_{\mathrm{Si}-\mathrm{H}}$ value of this a-SiN $\mathrm{x}_{\mathrm{x}}: \mathrm{H}$ film obtained from Figure $5(\mathrm{e})$ is too small $\left(<1.0 \times 10^{21} \mathrm{~cm}^{-3}\right)$ to evaluate the effect of bond-breaking of $\mathrm{Si}-\mathrm{H}$ on the decrease in the absorbance. Furthermore, a reduction due to the Si-N bond-breaking by oxidation is also expected. Although the reported values of the peak frequency in the $\mathrm{Si}-\mathrm{N}$ stretching mode vary between 835 - 875 $\mathrm{cm}^{-1}$ [7] [10] [11], the values are slightly higher than $v_{2}$ in the low-wavenumber side of the Si-N stretching mode.

As shown in Figure 4, the values obtained in this study are slightly higher than those reported by Tsu et al.; this is reasonable if we consider that oxidation already started in the as-deposited film. To clarify the mechanism of the initial oxidation process, including an assignment of $v_{2}$, further investigations are ongoing using samples having different $N_{\mathrm{Si}-\mathrm{H}}$ and $N_{\mathrm{N}-\mathrm{H}}$ values.

\section{Conclusion}

The a-SiN $\mathrm{x}_{\mathrm{x}} \mathrm{H}$ films grown in the present study through VHF-PECVD from a $\mathrm{SiH}_{4}-\mathrm{N}_{2}$ gas mixture are transparent in the visible region. The peak frequency of the $\mathrm{Si}-\mathrm{N}$ stretching mode increases with increasing $N_{\mathrm{N}-\mathrm{H}}$, which is similar to the behavior of a-SiN $\mathrm{x}: \mathrm{H}$ films grown from $\mathrm{SiH}_{4}-\mathrm{NH}_{3}$ gas. During film storage in dry air, the initial stage of oxidation was observed through in-situ IR measurement. The peak frequency of the Si-N stretching mode also increases in the initial stage of oxidation because of the increase of absorbance at the high-wavenumber side, and the decrease at the low-wavenumber side of the $\mathrm{Si}-\mathrm{N}$ stretching mode caused by an increase of the concentration of $\mathrm{O}$ atoms back-bonded to the $\mathrm{Si}$ atoms of the $\mathrm{Si}-\mathrm{N}$ bonds.

\section{Acknowledgements}

This work was partially supported by a Grant-in-Aid for Scientific Research (C) No. 15K04682 from the Ministry of Education, Culture, Sports, Science and Technology of 
Japan. I wish to acknowledge helpful discussions and encouragement from Professor Y. Hoshi.

\section{References}

[1] Heintze, M., Zedlitz, R. and Bauer, G.H. (1993) Analysis of High-Rate a-Si:H Deposition in a VHF Plasma. Journal of Physics D: Applied Physics, 26, 1781-1786.

[2] Fukawa, M., Suzuki, S., Guo, L., Kondo, M. and Matsuda, A. (2001) High Rate Growth of Microcrystalline Silicon Using a High-pressure Depletion Method with VHF Plasma. Solar Energy Materials and Solar Cells, 66, 217-223. http://dx.doi.org/10.1016/S0927-0248(00)00176-8

[3] Takagi, T., Takechi, K., Nakagawa, Y., Watabe, Y. and Nishida, S. (1998) High Rate Deposition of a-Si:H and a-SiNx:H by VHF PECVD. Vacuum, 51, 751-755. http://dx.doi.org/10.1016/S0042-207X(98)00284-X

[4] Kakiuchi, H., Nakahama, Y., Ohmi, H., Yasutake, K., Yoshii, K. and Mori Y. (2005) Investigation of Deposition Characteristics and Properties of High-rate Deposited Silicon Nitride Films Prepared by Atmospheric Pressure Plasma Chemical Vapor Deposition. Thin Solid Films, 479, 17-23. http://dx.doi.org/10.1016/j.tsf.2004.11.104

[5] Kobayashi, S., Ohrui, N., Chao, Y.C., Aoki, T., Kobayashi, H. and Asakawa, T. (2007) Deposition of Luminescent a-SiNx:H Films with $\mathrm{SiH}_{4}-\mathrm{N}_{2}$ Gas Mixture by VHF-PECVD Using Novel Impedance Matching Method. Journal of Materials Science: Materials in Electronics, 18, S29-S32.

[6] Lanford, W.A. and Rand, M.J. (1978) The Hydrogen Content of Plasma-Deposited Silicon Nitride. Journal of Applied Physics, 49, 2473-2477. http://dx.doi.org/10.1063/1.325095

[7] Demichelis, F., Giorgis, F. and Pirri, C.F. (1996) Compositional and Structural Analysis of Hydrogenated Amorphous Silicon-Nitrogen Alloys Prepared by Plasma-Enhanced Chemical Vapour Deposition. Philosophical Magazine B, 74, 155-168. http://dx.doi.org/10.1080/01418639608240333

[8] Smith, D.L. (1993) Controlling the Plasma Chemistry of Silicon Nitride and Oxide Deposition from Silane. Journal of Vacuum Science \& Technology A, 11, 1843-1850. http://dx.doi.org/10.1116/1.578436

[9] Tsu, D.V., Lucovsky, G. and Mantini, M.J. (1986) Local Atomic Structure in Thin Films of Silicon Nitride and Silicon Diimide Produced by Remote Plasma-enhanced ChemicalVapor Deposition. Physical Review B, 33, 7069-7076. http://dx.doi.org/10.1103/PhysRevB.33.7069

[10] Serra, J., Parada, E.G., Gonzalez, P., Fernandez, D., Chiussi, S., Pou, J., Leon, B. and Perez-Amor, M. (1996) Modification of Silicon Nitride Films to Oxynitrides by ArF Excimer Laser Irradiation. Surface and Coatings Technology, 80, 211-215. http://dx.doi.org/10.1016/0257-8972(95)02714-9

[11] Lucovsky, G., Yang, J., Chao, S.S., Tyler, J.E. and Czubatyj, W. (1983) Nitrogen-Bonding Environments in Glow-Discharge-Deposited a-Si:H Films. Physical Review B, 28, 32343240. http://dx.doi.org/10.1103/PhysRevB.28.3234 
Submit or recommend next manuscript to SCIRP and we will provide best service for you:

Accepting pre-submission inquiries through Email, Facebook, LinkedIn, Twitter, etc. A wide selection of journals (inclusive of 9 subjects, more than 200 journals)

Providing 24-hour high-quality service

User-friendly online submission system

Fair and swift peer-review system

Efficient typesetting and proofreading procedure

Display of the result of downloads and visits, as well as the number of cited articles

Maximum dissemination of your research work

Submit your manuscript at: http://papersubmission.scirp.org/

Or contact wjcmp@scirp.org 